\title{
Patent flurry casts cloud over gene silencing
}

\section{Erika Check, Washington}

A little-known Australian company has been granted a patent that it claims will give it wide-ranging rights over the use of genesilencing technology in mammals. And with other companies claiming rights to aspects of gene silencing - which has become a popular research tool and also holds therapeutic promise - academics fear that their access to the technology could become limited.

Gene silencing, also called RNA interference, enables researchers to shut off specific genes in cell cultures and in living organisms. Because the technique can switch off genes at different stages in development, it is a powerful tool for investigating gene function.

The company, Benitec of St Lucia in Queensland, has already been granted a patent for RNA interference in Australia. That patent is based on work done by scientists at Queensland's Department of Primary Industries which, company officials say, will ease the use of the technology in mammals, including humans.

The company claims that it will soon own similar rights to the technology worldwide. But the Queensland scientists have not yet published their results, and many other RNAinterference researchers and companies say that they haven't even heard of Benitec.

Over the past few years, corporate interest in gene silencing has expanded, with a host of biotechnology start-up companies filing competing patent claims. Some scientists have eagerly joined the fray, setting up their own companies to claim patent rights. Others have stuck to their research, hoping that the patent wars will not lead to restrictions on the free use of the technology.

Most observers consider it unlikely that academics will end up having to pay to use the technology, although Benitec has not ruled out the possibility, should its claims be granted. Meanwhile, patent offices have yet to rule on earlier patent claims made by some of the field's founders.

Gene silencing is thought to be a cellular defence against viruses and 'jumping' genes that can hop into the genome, disrupting normal gene function. It is activated when the cell detects an unusual RNA, such as one with paired strands. This RNA is cut into fragments some 21 nucleotides long by an enzyme called Dicer. Single strands from these fragments, called small interfering RNAs, then bind to the alien RNA, which is disabled. But this defence mechanism can be targeted against the cell's own genes by adding double-stranded RNA with the corresponding sequences (see diagram).

It was only in 1998 that Andrew Fire, a developmental biologist at the Carnegie Institution of Washington, showed that a

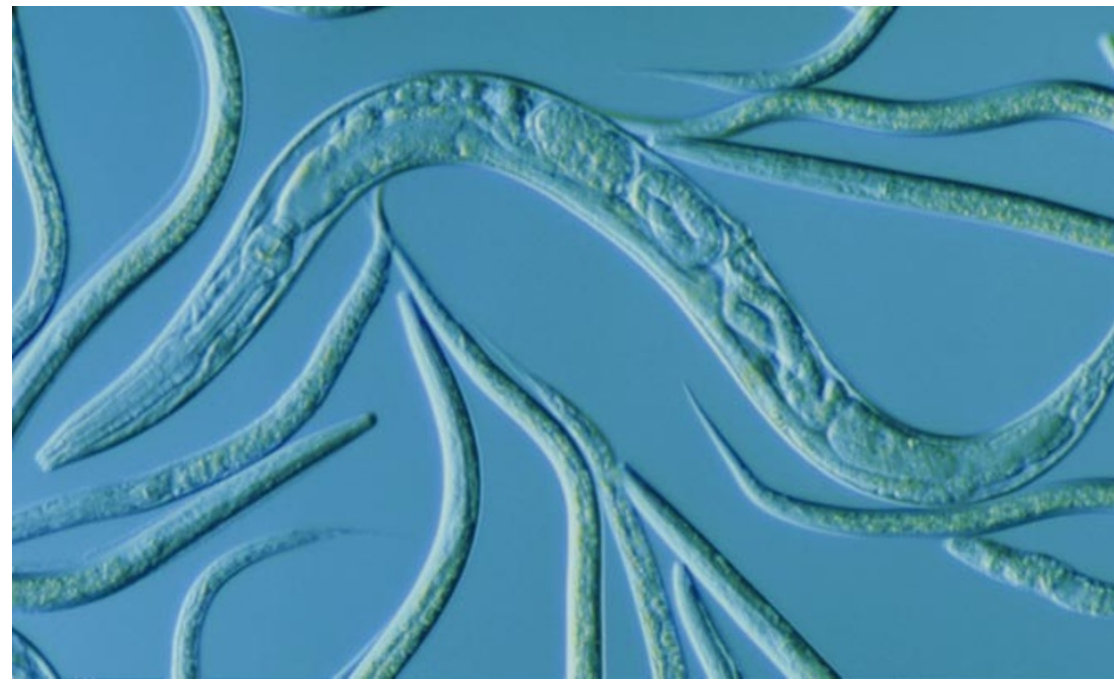

Switched off: gene silencing was demonstrated in the nematode Caenorhabditis elegans in 1998.

gene-silencing pathway exists in animals. Fire and his colleagues injected doublestranded RNA into cells from the nematode Caenorhabditis elegans and 'silenced' specific genes (A. Fire et al. Nature 391, 806-811; 1998). Fire filed a US patent application in 1997, and hopes that it will be granted later this year. This application is thought to be the earliest to set out how the technology works in animals.

But Fire's technique does not work in mammals - the infusions of long RNA strands kill mammalian cells. Last year, Tom Tuschl at the Max-Planck-Institute for Biophysical Chemistry in Göttingen got around this problem by introducing small interfering RNAs directly into mouse cells (S. M. Elbashir et al. Nature 411, 494-498; 2001). Tuschl's discovery attracted additional venture capital to the field, because it meant that the technology might be used to create therapies for humans.

\section{Silent treatment}

Tuschl and Phillip Sharp, his mentor at the Massachusetts Institute of Technology, applied for a patent on their RNA-interference method in 2000. Tuschl subsequently sought a patent for the use of the technique in mammals. But other groups had already applied for patents in other vertebrates, or on small pieces of RNA in invertebrates. For example, Ribopharma of Kulmbach, Germany, earned a German patent on RNA interference in April. That patent covers only short pieces of RNA.

Benitec says that it has developed a technique that entirely circumvents the problem with mammalian cells by using a vector to get long RNA strands into the cell. It uses a DNA construct that is transcribed within the cell into a single strand of RNA. This strand then

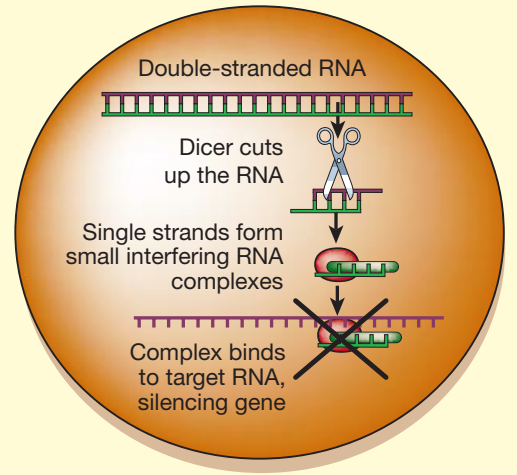

Gagging order: using double-stranded RNA, specific genes within a cell can be silenced.

folds into a hairpin shape, which is recognized by the cell as double-stranded RNA.

Benitec and Ribopharma are only the first in a line of firms getting ready to claim patent rights on some aspect of gene silencing. Another set of firms, including Nucleonics of Malvern, Pennsylvania, Devgen of Ghent, Belgium, and Cenix BioScience of Dresden, Germany, plan to profit from the technology by using it to screen for drug targets. Sharp is also said to be starting a drug-discovery company.

While these companies wait for patent offices to sort out competing claims, they are hoping to avoid large licensing fees on the technology. "The patent situation is a mess," says Tony Giordano, president of Nucleonics.

Fire is pleased that gene silencing has inspired so much excitement. But he hopes that scientists will not lose free access to it. "This is too important a technology to be restricted," Fire says. "I would be really upset if the people doing basic research had to pay a fee." 